\title{
A STUDY ON THE USE OF WEATHER INFORMATION IN CONSTRUCTION SCHEDULE MANAGEMENT
}

\author{
$\underline{\text { Jung Min Lim }}{ }^{1}$, Seung Kyu Yoo ${ }^{1}$, Ju Hyung Kim², and Jae Jun Kim²* \\ ${ }^{1}$ Department of Sustainable Architectural Engineering, Hanyang University, Seoul, Korea \\ ${ }^{2}$ Department of Architectural Engineering, Hanyang University, Seoul, Korea \\ *Corresponding author (jjkim@hanyang.ac.kr)
}

\begin{abstract}
Recently, the abnormal climatic changes have been frequently occurred all over world. Construction work is heavily affected by weather because it is mostly performed outdoors unlike other industries. But construction schedule management is not considered by weather in many construction sites and construction work relied on the experience and subjective point of view by superintendent of construction site. That's why the delay of construction is frequently occurred. In order to recovery the delay of construction period, Construction Company carries out their construction by force to reduce the construction period so, poor construction, low quality, negligent accident are occurred. In order to solve these problems, basic study is to be carried out with analysis data of existing study and application of weather information.
\end{abstract}

Keywords: Delay of Construction Period, Process Management, Weather

\section{Introduction}

\subsection{Background and purpose}

Korea is characterized by having four distinct seasons so, there are many climatic changes such as heat waves in summer or cold weather in winter.

Especially for the climatic elements such as temperature, rainfall, snowfall, etc, these are most closely related to delay of construction period among other unpredictable elements. Consequently, some of clients including the Korea Housing, they compensate for the delay damage of construction period if there is delay of construction period due to the weather. But the increased construction cost is generally transferred to Construction Company in the most of private construction work. [Minchul Han 2010] In spite of these disadvantageous conditions, estimate of construction period depends on the experience and subjective judgment of superintendent so it causes the problems such as delay of construction period and low quality, etc. If construction work is planned in consideration of weather, it can prevent the delay of construction period and increase of prime cost. Also it reduces the damage and increases the profits. Therefore, this study proposes the method of using weather information of temperature, rainfall and snowfall for construction schedule management.

\section{Theological Consideration}

\subsection{Consideration of existing studies}

The climatic elements and its related existing study in Korea are described as below table 1 . It contains the estimate of non working day and estimate of construction period, evaluation of productivity, etc by using weather information of the past.

Table1. Existing studies

\begin{tabular}{l|l|l}
\hline Researcher & Year & Contents \\
\hline Chongchul, & 1999 & $\begin{array}{l}\text { Suggestion of deciding the time for } \\
\text { reduction of construction period and } \\
\text { commence of construction in } \\
\text { consideration of regional climatic } \\
\text { characteristics when estimating the } \\
\text { construction period of apartment }\end{array}$ \\
\hline Jung & 2000 & $\begin{array}{l}\text { Suggestion of making decision } \\
\text { model of estimate of construction } \\
\text { period with calculating non- } \\
\text { workable days by simulation by } \\
\text { analysis and statistics for each } \\
\text { climatic factors affected in unit }\end{array}$ \\
\hline
\end{tabular}




\begin{tabular}{l|l|l}
\hline & & process \\
\hline Kintae, & 2004 & $\begin{array}{l}\text { Suggestion of result of climatic } \\
\text { factor by regression analysis for past } \\
30 \text { years with correlation between } \\
\text { climate and productivity as basic } \\
\text { data of management for type of } \\
\text { construction in the process of } \\
\text { reinforcing bar concrete frame work } \\
\text { of apartment house }\end{array}$ \\
\hline Jonghyun & 2005 & $\begin{array}{l}\text { Estimate of non-workable days } \\
\text { focusing on the Incheon by analysis } \\
\text { of affect of climatic factors on the } \\
\text { construction period }\end{array}$ \\
\hline $\begin{array}{l}\text { Heeman, } \\
\text { Chae }\end{array}$ & 2007 & $\begin{array}{l}\text { Analysis of non-workable days by } \\
\text { regression analysis of temperature in } \\
\text { Seoul for 46 years }\end{array}$ \\
\hline Jaewon & 2007 & $\begin{array}{l}\text { Estimate of frame work period by } \\
\text { simulation of virtual climate with } \\
\text { method for estimate of construction } \\
\text { period by climatic information for } \\
\text { high-rise building }\end{array}$ \\
\hline
\end{tabular}

\section{Climatic elements and process management}

\subsection{Climatic elements for construction work}

Weather is called standby status ranged over the times and days in random time and place. There are rainfall, temperature and wind in major influence factor for construction.

Climate has various influences for each element in construction work. Characteristics for each climatic fact should be understood and correlation with work elements should be considered and applied because there are many differences depending on the location and method of work and etc.

\subsubsection{Rainfall}

Rainfall has various influences in each work site. The work is divided into indoor and outdoor construction site.

Indoor construction such as interior finishing work or equipment construction, etc has little influences by rainfall but, but construction is not available especially in earth work, ground work and frame work.

Table 2 Non-workable rainfall

\begin{tabular}{c|l}
\hline The Korea Housing & Over 10mm of rainfall per day \\
\hline $\begin{array}{c}\text { U.S Army } \\
\text { Construction Work }\end{array}$ & Over $5 \mathrm{~mm}$ of rainfall per day \\
\hline $\begin{array}{c}\text { Industry Safety } \\
\text { Standards }\end{array}$ & Over $1 \mathrm{~mm}$ per hour \\
\hline
\end{tabular}

\subsubsection{Temperature}

If the temperature is below $0{ }^{\circ} \mathrm{C}$, frozen cement has bad influence on the hardening of cement. Also, it affects the form remaining period when the temperature is between 0 to $10^{\circ} \mathrm{C}$.

If the temperature is over $25^{\circ} \mathrm{C}$, it can cause the quality problem in concrete placing and low productivity in frame work and partial finishing work can be lower when it's high temperature in the afternoon. Or it can be not workable as well.

Table 3.Non-workable temperature

\begin{tabular}{|c|c|c|}
\hline & $\begin{array}{c}\text { Standard of low } \\
\text { temperature }\end{array}$ & $\begin{array}{l}\text { Standard of high } \\
\text { temperature }\end{array}$ \\
\hline $\begin{array}{l}\text { The Korea } \\
\text { Housing }\end{array}$ & $\begin{array}{l}\text { Cold weather } \\
\text { concrete when } \\
\text { it’s below } 4^{\circ} \mathrm{C} \\
\text { for daily } \\
\text { average } \\
\text { temperature }\end{array}$ & $\begin{array}{c}\text { Hot-weather } \\
\text { concrete when it's } \\
\text { over } 25^{\circ} \mathrm{C} \text { for daily } \\
\text { average } \\
\text { temperature }\end{array}$ \\
\hline $\begin{array}{c}\text { U.S Army } \\
\text { Construction } \\
\text { Work }\end{array}$ & \multicolumn{2}{|c|}{$\begin{array}{c}\text { Below } 0{ }^{\circ} \mathrm{C} \text { for daily average } \\
\text { temperature }\end{array}$} \\
\hline $\begin{array}{l}\text { the Korea } \\
\text { Highway } \\
\text { Corporation }\end{array}$ & $\begin{array}{c}\text { Below } 4{ }^{\circ} \mathrm{C} \text { for } \\
\text { daily average } \\
\text { temperature }\end{array}$ & $\begin{array}{c}\text { Over } 35^{\circ} \mathrm{C} \text { for } \\
\text { daily average } \\
\text { temperature }\end{array}$ \\
\hline
\end{tabular}

\subsubsection{Wind}

The non-workable standard by wind is as below and it is defined in Industrial Safety Standard.

Table 4. Non-working figures by wind speed

\begin{tabular}{l|l}
\hline & Specification \\
\hline Industry Safety & Over $10 \mathrm{~m} / \mathrm{s}$ for maximum speed of \\
Standards & wind \\
\hline
\end{tabular}

\subsection{Process management of construction work}

As for the plan of construction in construction work, it can be defined that it is to construct the buildings safely with minimum cost within given construction period based on the design book. During this process, most basic plan is 
process management. The direct purpose of process management is to secure the period of construction.

Construction can be carried out or suspended in accordance of weather. So, weather should be predicted when setting up the construction plan.

\section{Conclusion}

This study is to consider the estimate of non-working days and estimate of construction period, evaluation of productivity based on the existing studies. There have been many efforts to use the climatic information in process management but it ends up using only previous data. This is basic study to the system managing the construction by using the climatic information at the construction stage in real time in order to improve this issue.

The influence of accumulated weather information, the development of system by analysis of actual cases and the specification defined by various public organizations and private companies on construction work needs to be reviewed.

\section{REFERENCES}

[1] Minchul Han., "A Study on the Estimation of Nonworking Days Due to Climatic Condition”, The Industrial Science Researches, Vol. 27(2), pp. 2-4, 2010.

[2] Bongchu.l Choi., "Byeongchul Choi "A Study on the effect of climatic factor on estimate of construction period for apartment Building”, Abstracts of Presentations at the Spring Meeting of the Architectural Institute of Korea, (Structure and Construction), Vol. 19(2), 1999,

[4] Jungseok Nam and 1 other writer., "Relationship Between Construction Productivity and the Weather Elements in the Reinforced Concrete Structure for the High-rise Apartment Buildings”,Abstracts of Presentations at the Spring Meeting of the Architectural Institute of Korea,, Vol. 1(4), 2000.

[5] Sintae Kim, Yaesang Kim, Sanyun Jin "Relationship Between Construction Productivity and the Weather Elements”, Korean Journal of Construction Engineering and Management, Vol. 5(6), pp. 80-89, 2004.

[6] Jonghyun Shin, Jina Lee, Chansik Lee, “The Estimation of Non-Working days for the Construction Project in Incheon Region”,Korean Journal of Construction Engineering and Management, Vol. 6(1), pp. 58-64, 2005.
[7] Heeman Chae., "Influence of the Global Warming in Domestic Construction Schedules", Abstracts of Presentations at the Meeting of the Architectural Institute of Korea ,. pp.567-570, 2007.

[8] Jaewon Shin.,"Probabilistic Model to Forecast the Duration of Structural Work in High-rise Building Construction Considering Weather Elements”, Journal of the Architectural Institute of Korea Structure and Construction, Vol. 23(6), pp. 123-132, 2007. 